\title{
(6) \\ Rare cause of massive haemoptysis in pulmonary tuberculosis: Rasmussen's aneurysm
} OPEN ACCESS

\author{
Sankar Neelakantan, Rakesh Anandarajan, Anil Kumar Swamy
}

Department of Radiology, St Johns Medical College and Hospital, Bangalore, Karnataka, India

\section{Correspondence to} Dr Sankar Neelakantan, dr.sankar@live.com

Accepted 6 October 2016
CrossMark

To cite: Neelakantan $S$ Anandarajan R, Swamy AK. BMJ Case Rep Published online: [please include Day Month Year] doi:10.1136/ bcr-2016-216652

\section{DESCRIPTION}

A woman aged 48 years presented to the accident and emergency department with three episodes of massive haemoptysis of $\sim 500 \mathrm{~mL}$. On examination, her vitals were stable. She had a history of pulmonary tuberculosis 2 years prior to this episode for which she had taken a complete course of antituberculous drugs for 9 months and was symptomfree and sputum culture-negative at the end of treatment. Her blood routines showed leucocytosis and raised inflammatory markers (ESR). Sputum and bronchoalveolar lavage specimens were smear positive for acid-fast bacilli, thus she was diagnosed to have a relapse with active tuberculosis.

Imaging evaluation included a chest radiograph which showed cavitatory lesions with air fluid levels in bilateral lung fields with surrounding air space shadowing (figure 1). A plain multidetector CT (MDCT) was performed, which revealed multiple discrete cavities randomly distributed throughout both lungs (figure 2) and the largest cavity was in the right lower lobe and had hyperdense (blood density) contents within (figure 3). A contrastenhanced MDCT angiography revealed a well defined, spherical, intracavitary wall-based lesion with homogenous intense enhancement similar to aorta in arterial phase images (figure 4). A branch from the descending right pulmonary artery was noted leading into the lesion (figure 5). The lesion was diagnosed as a Rasmussen's aneurysm within a tubercular cavity. The patient requested a discharge against medical advice and was lost to follow-up.

Massive haemoptysis in cases with underlying tuberculosis can be due to varied aetiopathologies

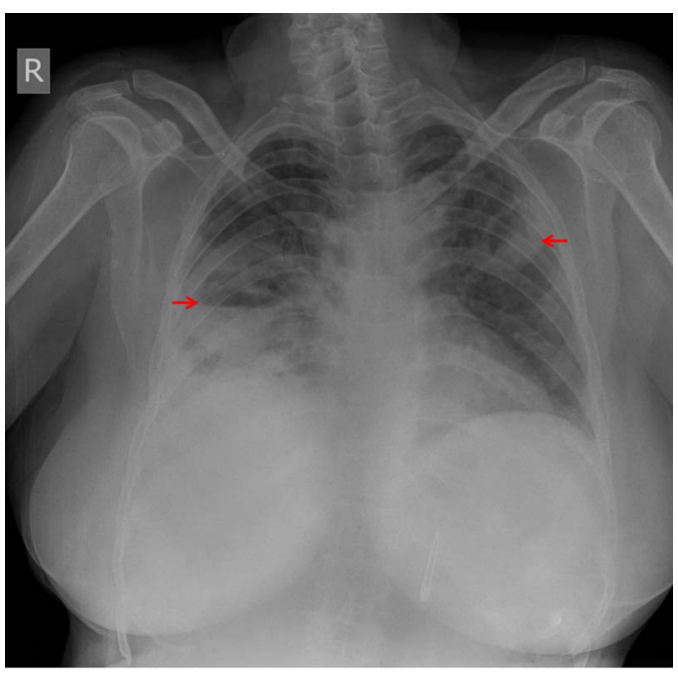

Figure 1 Plain chest radiograph showing cavitary lesions in both lung fields (arrows) with surrounding air space opacities and right costophrenic angle blunting. like bronchiectasis, aspergillomas, broncholiths or vascular abnormalities. Of the vascular complications, bronchial arteries are the most common source of haemorrhage and the pulmonary arteries account for $<10 \%$ of haemoptysis. ${ }^{1}$

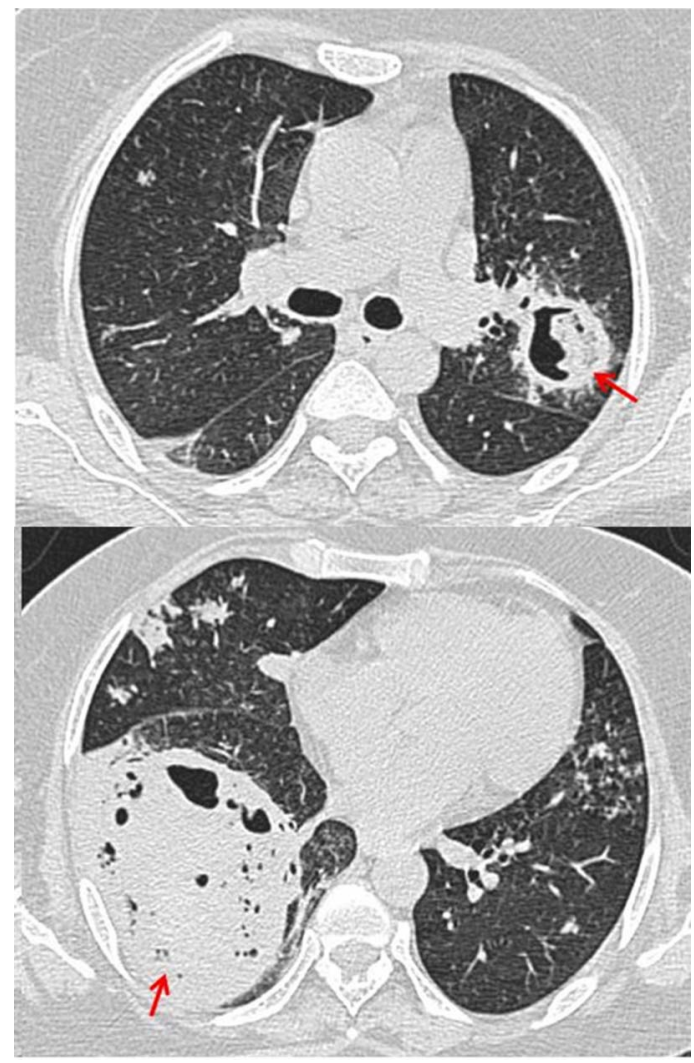

Figure 2 Axial plain multidetector CT sections of chest in lung window showing well-defined cavitary lesions in both lung fields (arrows).

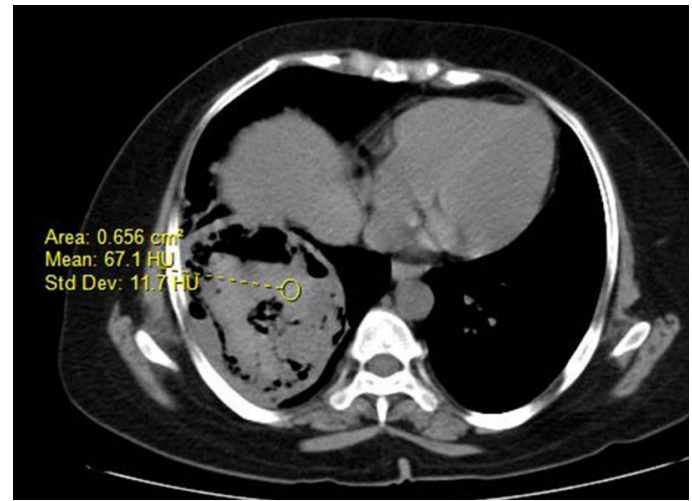

Figure 3 Axial plain multidetector CT section of chest in soft tissue window showing hyperdense intracavitary contents (blood density). 


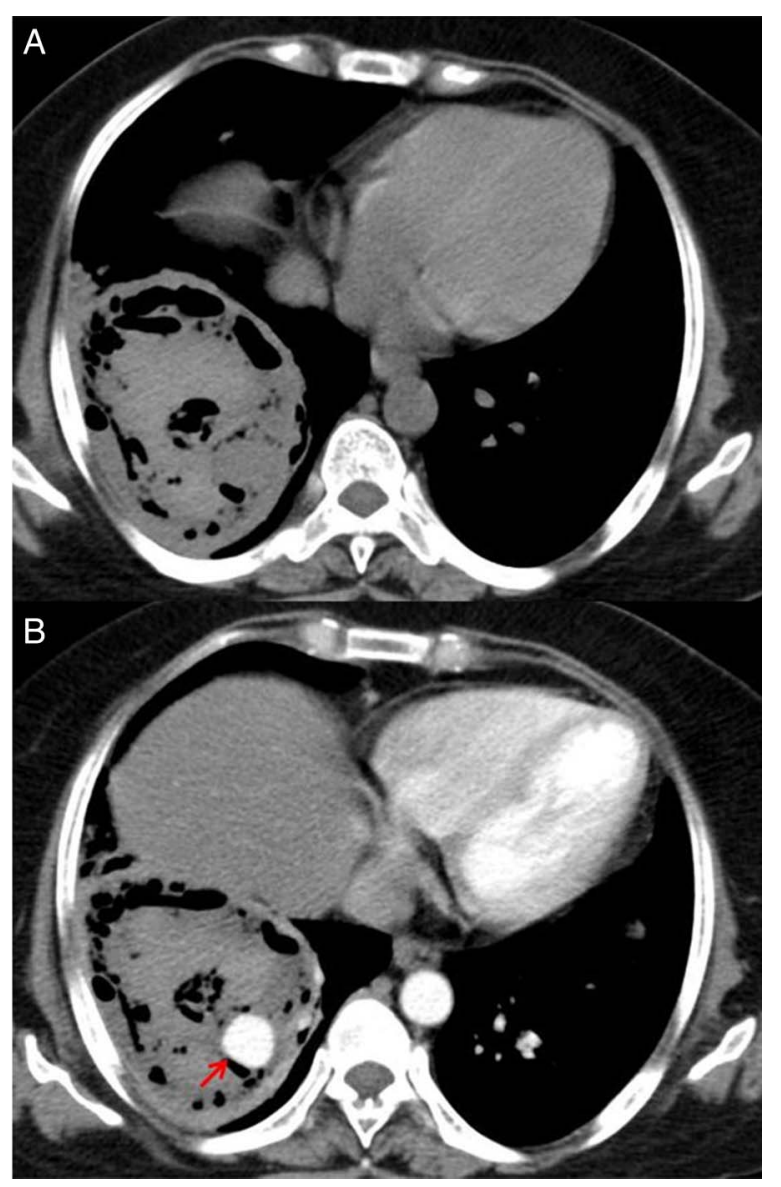

Figure 4 Axial plain (A) and contrast-enhanced (B) multidetector CT sections of chest showing a well defined, spherical, intracavitary wall-based lesion with homogenous intense enhancement similar to aorta in arterial phase images (arrow).

Rasmussen's aneurysm is a focal dilation of a branch of the pulmonary artery due to arterial wall erosion secondary to chronic inflammation within a tubercular cavity. Arteries involved are small to medium-sized branch vessels; therefore,

\section{Learning points}

- Rasmussen's aneurysm is an inflammatory dilation of a branch of the pulmonary artery adjacent to or within a tubercular cavity.

- Rasmussen's aneurysm needs to be differentiated from a bronchial or systemic source of bleeding by using multidetector CT angiography.

- Endovascular techniques like catheter-assisted arterial embolisation are the preferred therapeutic modality for massive haemoptysis due to inflammatory aneurysms.

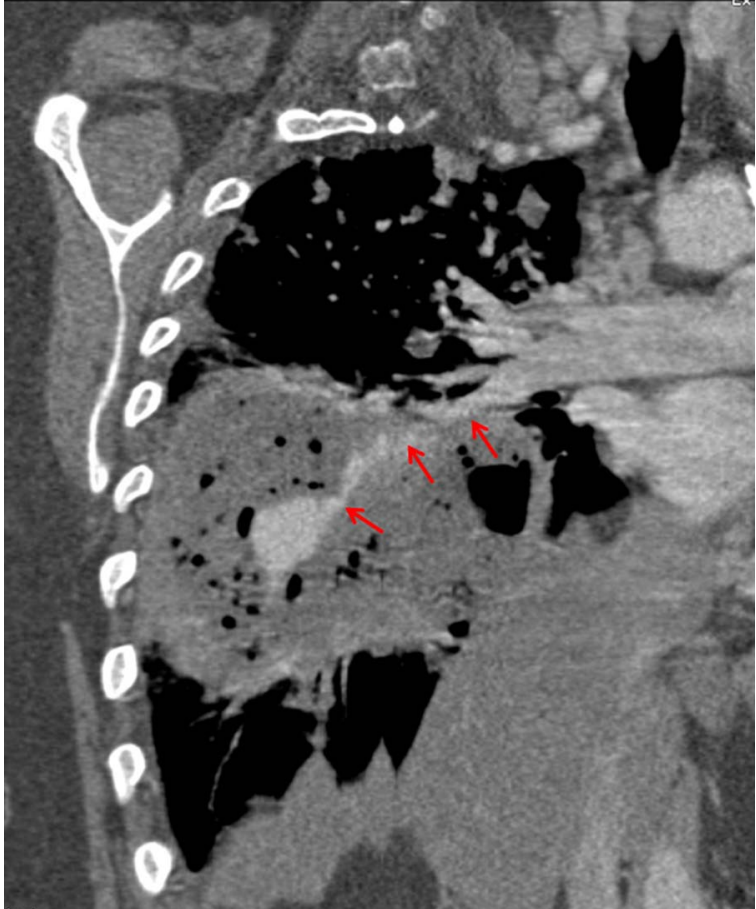

Figure 5 Coronal MPR reformatted image showing a branch from the right descending pulmonary artery leading into the aneurysm (arrows).

the aneurysms are usually peripherally located. The reported incidence is around $5 \%$ in cavitatory tuberculosis. ${ }^{2}$

It is an entity that requires urgent clinical differentiation from bronchial arterial sources of bleeding, due to higher relative intravascular pressures in bronchial circulation which is more challenging to treat, leading to poor outcomes. ${ }^{2}$

Emergency endovascular techniques like arterial embolisation are the preferred treatment modality for massive haemoptysis due to inflammatory aneurysms. ${ }^{3}$

Twitter Follow Sankar Neelakantan at @drsankar23

Contributors $\mathrm{SN}$ is responsible for conceptualisation, write up and editing. RA and AKS are responsible for images.

Competing interests None declared.

Patient consent Obtained.

Provenance and peer review Not commissioned; externally peer reviewed.

Open Access This is an Open Access article distributed in accordance with the Creative Commons Attribution Non Commercial (CC BY-NC 4.0) license, which permits others to distribute, remix, adapt, build upon this work non-commercially, and license their derivative works on different terms, provided the original work is properly cited and the use is non-commercial. See: http://creativecommons.org/ licenses/by-nc/4.0/

\section{REFERENCES}

1 Keeling AN, Costello R, Lee MJ. Rasmussen's aneurysm: a forgotten entity? Cardiovasc Interv Radiol 2008;31:196-200.

2 Shih SY, Tsai IC, Chang YT, et al. Fatal haemoptysis caused by a ruptured Rasmussen's aneurysm. Thorax 2011:66:553-4.

3 Lombardi MA, Gheur M, Faivre JB, et al. Rasmussen aneurysm. JBR-BTR 2014:97:372. 
Copyright 2016 BMJ Publishing Group. All rights reserved. For permission to reuse any of this content visit http://group.bmj.com/group/rights-licensing/permissions.

BMJ Case Report Fellows may re-use this article for personal use and teaching without any further permission.

Become a Fellow of BMJ Case Reports today and you can:

- Submit as many cases as you like

- Enjoy fast sympathetic peer review and rapid publication of accepted articles

- Access all the published articles

- Re-use any of the published material for personal use and teaching without further permission

For information on Institutional Fellowships contact consortiasales@bmjgroup.com

Visit casereports.bmj.com for more articles like this and to become a Fellow 